\title{
The introduction of category management in the procurement activities of an oil company in a digital transformation
}

\author{
Elvira Khalikova \\ Ufa State Petroleum Technological \\ University \\ Ufa, Russia \\ ydacha6@yandex.ru, 0000-0003-1197- \\ 5420
}

\author{
Tatyana Leybert \\ Ufa State Petroleum Technological \\ University \\ Ufa, Russia \\ lejjbert@mail.ru,0000-0001-9009- \\ 5557
}

\begin{abstract}
The implementation of the concept of digitalization of the business in procurement requires management of the oil company a fundamentally new management decisions based on reliable business intelligence and analytical tools. As such, advocates the concept of category management and analytical tools, the use of which allows to obtain qualitatively new information about goods, works, services, suppliers, markets, procurement and much more. However, this information is stored in a database, the wide use of which will allow the company to build a reasonable and effective strategy in procurement.

This article shows you how to integrate modern digital technology and tools of category management to improve the efficiency of procurement activities in oil companies. Presented developed by the authors of tools of categorization in the procurement process for the formation of business intelligence. An algorithm for the implementation of category management in the procurement unit in the oil company, which is based on the block diagram of the business process "Procurement" and methodical principles of the ABC-analysis, SHM - analysis, categorical analysis, procurement and suppliers, as well as methods of assessing the effectiveness of procurement activities. Also the authors indicated the subject area of procurement, the implementation of which should be carried out on the basis of information technologies of BIG DATA and business intelligence.
\end{abstract}

Keywords-digital business transformation, digital technologies, BIG DATA, category management, category strategy, procurement, oil company

\section{INTRODUCTION}

Digital transformation of economic systems in Russia is one of the strategic priorities, key goals of which should be the process of forming a cross-functional competencies that characterize the ability of using information communication technologies for the digital environment, which interact with the company of a particular industry, related with the business sector and society. This will contribute to the solution of digital problems of professional activities.

Today, the modern world community discusses issues of digital business transformation, related to the mass introduction of digital technologies in business processes of companies. The main elements of digital technologies include: mobility, cloud computing, Internet of things, augmented reality, robotics, processing technology, big data, business intelligence. As noted by leading economists of Microsoft, the combined impact of these technologies will lead to the expansion of the value chain of the business and to improve efficiency in companies. A large number of analytical studies, consulting companies and research institutes for the assessment of the financial effect of the introduction of digital solutions in various business processes. So, according to estimates, more than $30 \%$ of digital solutions widely introduced in such business processes as purchase management, logistics management and customer relationship management, the system of calculations with use of electronic digital signature, management of production equipment, electronic system of internal documentation. In supply chain management and systems logistics chief digital drivers were unmanned vehicles and drones, various sensors and operating the monitoring of the movement of material values, exoskeletons to assist the person to the warehouse operations, the blockchain technology, smart contracts [1].

The business transformation has affected the oil companies, management which understands that instability in the macroeconomic and political processes in the country led to complexity and to the impossibility of predicting outcomes activities for the long term. Therefore, the main vector of efficiency and economic security oil company is a comprehensive business transformation, based on qualitative change of the business model of the company, its controllability, and flexibility [2]. Comprehensive transformation concerns not only the business processes but also schemes and formats management. One of the main blocks in the value chain of an oil company is a unit of procurement, the efficiency of which largely depends on the flexibility and bifunktionality the management system, and the use of modern methods of procurement management.

\section{Problem StATEMENT}

In the context of the transition to digital transformation, most oil companies understand that the old classical strategies, the purpose of which was to most specifically visualize the final result and achieve it at a certain point in time, do not work, and today the company cannot predict the desired result with a high degree of probability and determine the exact requirements for the final result.

One of the main principles of the oil company is the creation of such a company, which ultimately will make decisions based on data and their analytics. And business process management will not be a closed system, but part of a single value chain of a company that has cross-functional 
interaction with other business processes. The head of the business process management system is the database and its analytics (BIG DATA) and management tools based on it.

The introduction of BIG DATA and modern management tools in the procurement unit of the oil company is also an urgent task, as the strategies for selecting suppliers and procurement contracting are changing. The rationale for procurement should be based not only on the principles of transparency, ensuring a competitive environment, preventing a corruption component, but also on evaluating the effectiveness of procurement based on the total cost of ownership of certain categories of goods, works and services.

Given the fact that the oil company procurement meets the needs of different business areas, ranging from exploration, well drilling and ending with the sale of oil and oil products, the maintenance of offshore drilling platforms, the procurement management system itself should not end only with uninterrupted supply production processes of material and technical resources, work and services, and should include an assessment of the effectiveness of their ownership, taking into account the life cycle th resource, work and services. This circumstance necessitates the creation of a database of suppliers, goods, works, services for various categories and criteria, and, consequently, a database of certain analytics to increase the efficiency of procurement activities.

\section{METHODOLOGY}

Considering the procurement activities in the oil company as an independent business process, it can be divided into seven main stages: the formation of the need for material and technical resources (MTR) and production services (PS), the management of procurement categories and the PU catalog, the planning of procurement procedures, the transfer of needs to the procurement block and initiation, selection of a counterparty, management of contract execution, counterparty management. The general scheme of the business process "Purchasing Activities in an Oil Company" is presented in Figure 1.

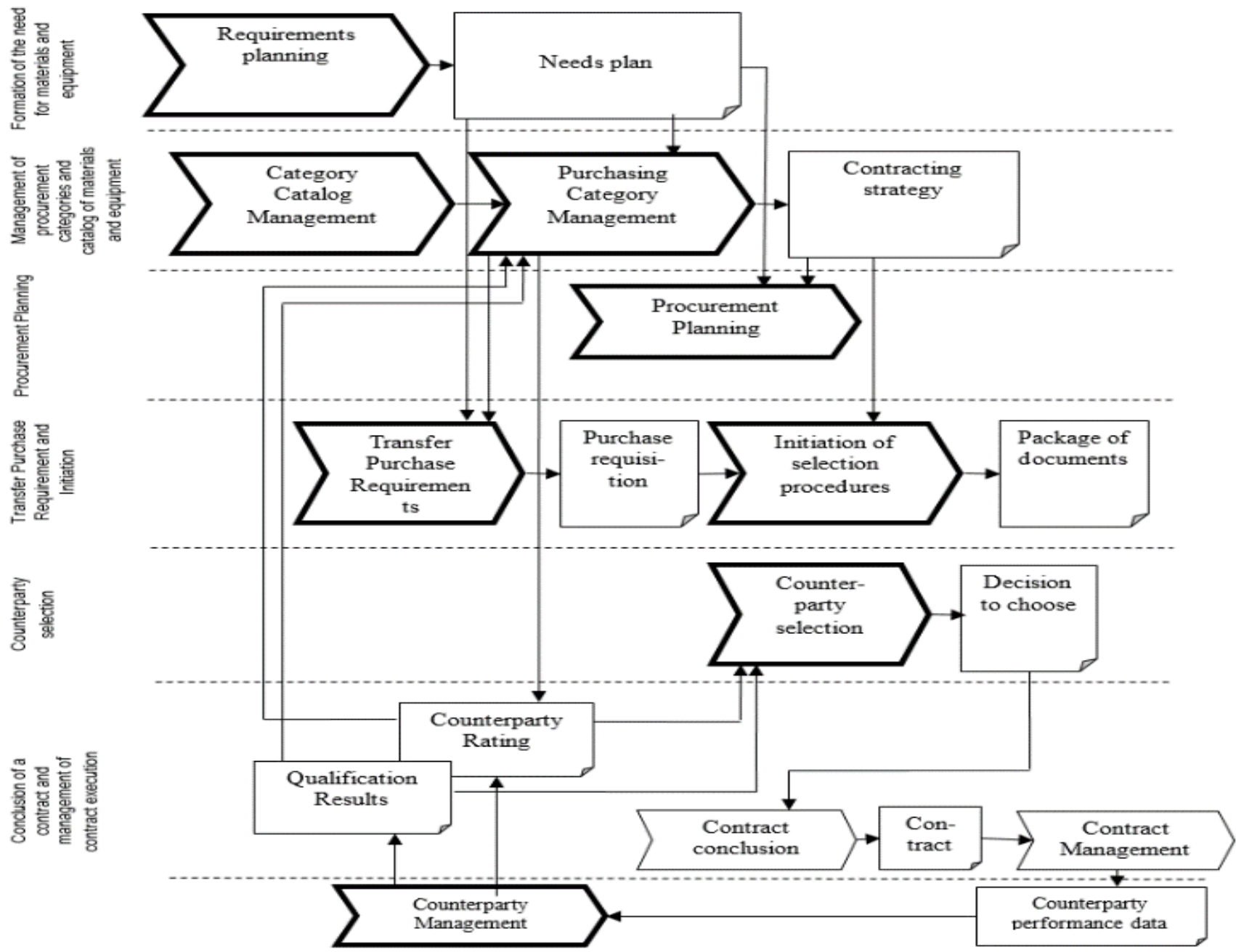

Fig. 1. The general scheme of the business process "Procurement in the oil company" 
The aim of the process with procurement of materials and PU is the timely provision of the needs of the production functions in inventory, manufacturing services and works with the required quality level and optimal cost. To achieve this basic function before all the structural divisions of the oil companies in the area of procurement, are as follows:

- ensuring of timely purchase of inventory and PS;

- providing of economic efficiency of the procurement of MTR and PS;

- the choice of counterparty is able and willing to ensure the quality of MTR and PS and the high level of production security in the supply of materials and equipment providing PS;

- ensure a high level of service provided for the purchase of inventory and PS.

Part of the above task is solved by the methods and tools of category management, where the main goal is the differentiation of main categories of procurement (procurement category, category, vendor, category, material and technical resources, categories, production services and works) for effective procurement management.

Categorical approach to procurement requires a procurement process clearly allocated areas for procurement categories and regular update of cooperation with domestic customers category strategies.

It should be agreed with the procurement specialist $\mathrm{O}$. Kanenkova, who notes the inextricable link between the procurement strategy and the company's strategy. "It is not possible to efficiently purchase without understanding exactly what to buy, from whom and at what price. The procurement strategy is a clear vision of relations with suppliers for the long term" [3]. At the same time, the procurement strategy should include the strategy of certain product groups, building procurement processes and, as a consequence, the introduction of digital technologies.

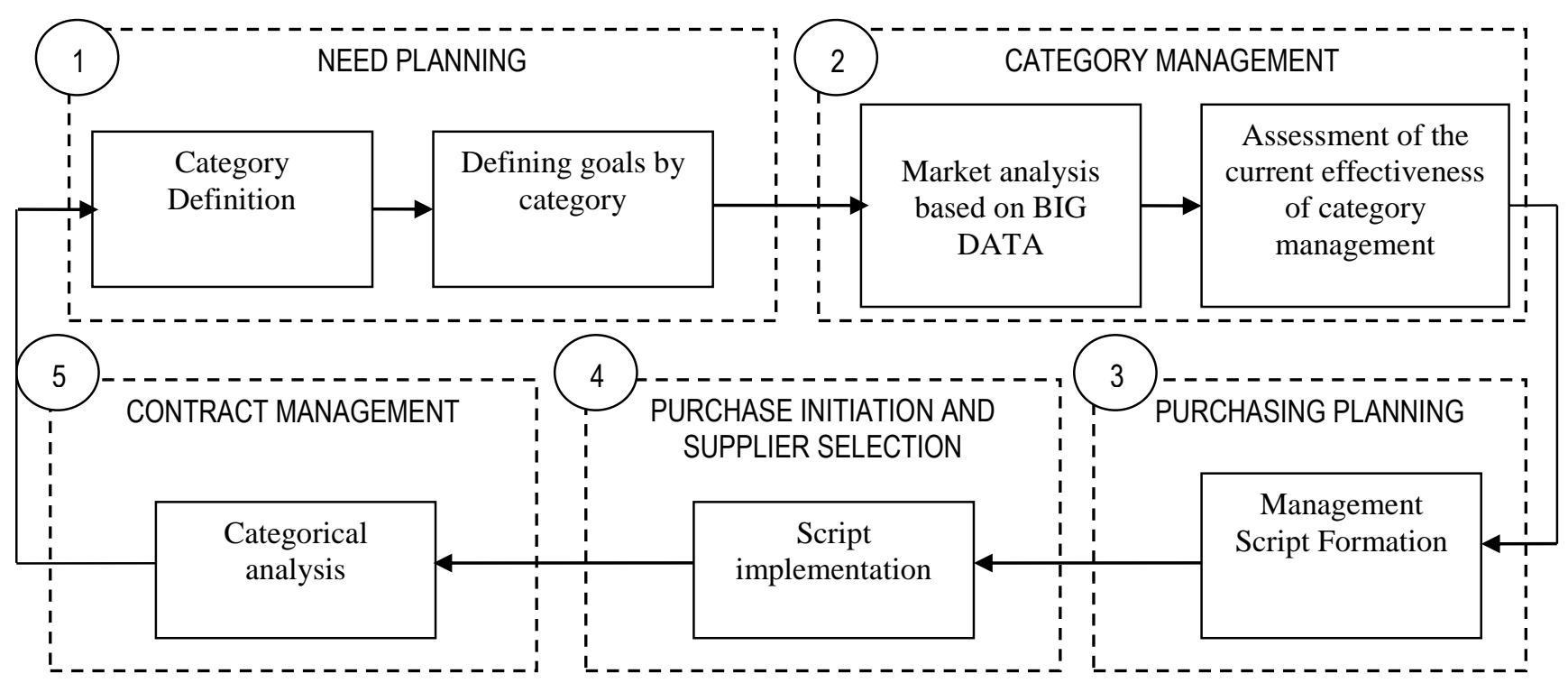

Fig. 2. Algorithm for introducing category management into the procurement unit at an oil company

To develop categorical strategies in procurement, a large business analytics should be used, based on the collection of a large array of internal corporate information. Such information may include: distribution of suppliers and goods by category, risk analysis by category, analytical information on procurement costs, cost structure, information on the total cost of ownership of materials and equipment $[4,5]$.

So, in one of the largest oil companies, there is a subsystem for managing the categories of procurement of production works and services in the Upstream. This process consists of determining the procurement category of PSs, developing and managing a sector strategy and contracting strategy for a particular procurement category. Categorization of purchases within the framework of the oil company in order to determine the best instruments and procurement practices for the selected group of PS. Examples of such tools can be a unified contracting strategy, unified approaches to the pricing structure and carrying out procedures for selecting counterparties, etc. PSs belonging to one or several PS sectors, as well as to one or several lists of PSs, can be combined into the procurement category.
In the framework of this scientific study, the authors of the article consider the algorithm for introducing category management into the procurement block, the elements of which are used at certain stages of the procurement activity in the oil company (Figure 2).

Of the presented in Figure 1, 5 stages were identified in which the principles of categorization, analytical tools and business analytics will be used.

At the planning stage of the need, procurement categories are formed and a procurement strategy is determined for a particular category of materials and equipment. At the second stage, an analysis of the market for goods of a particular category is carried out; a current assessment of the effectiveness of managing this category is carried out with the identification of risks of the external and internal environment.

At the procurement planning stage, procurement scenarios are formed related to the system of pricing, selection of suppliers, contracting, and contract execution control. At the stage of supplier selection and procurement initiation, counterparties are rated based on the selected selection categories. At the stage of managing contract execution, a 
categorical analysis of the terms of contract execution is carried out for each category of supplier by the level of its significance for the oil company.

MAIN STAGES OF THE PROCUREMENT PROCESS

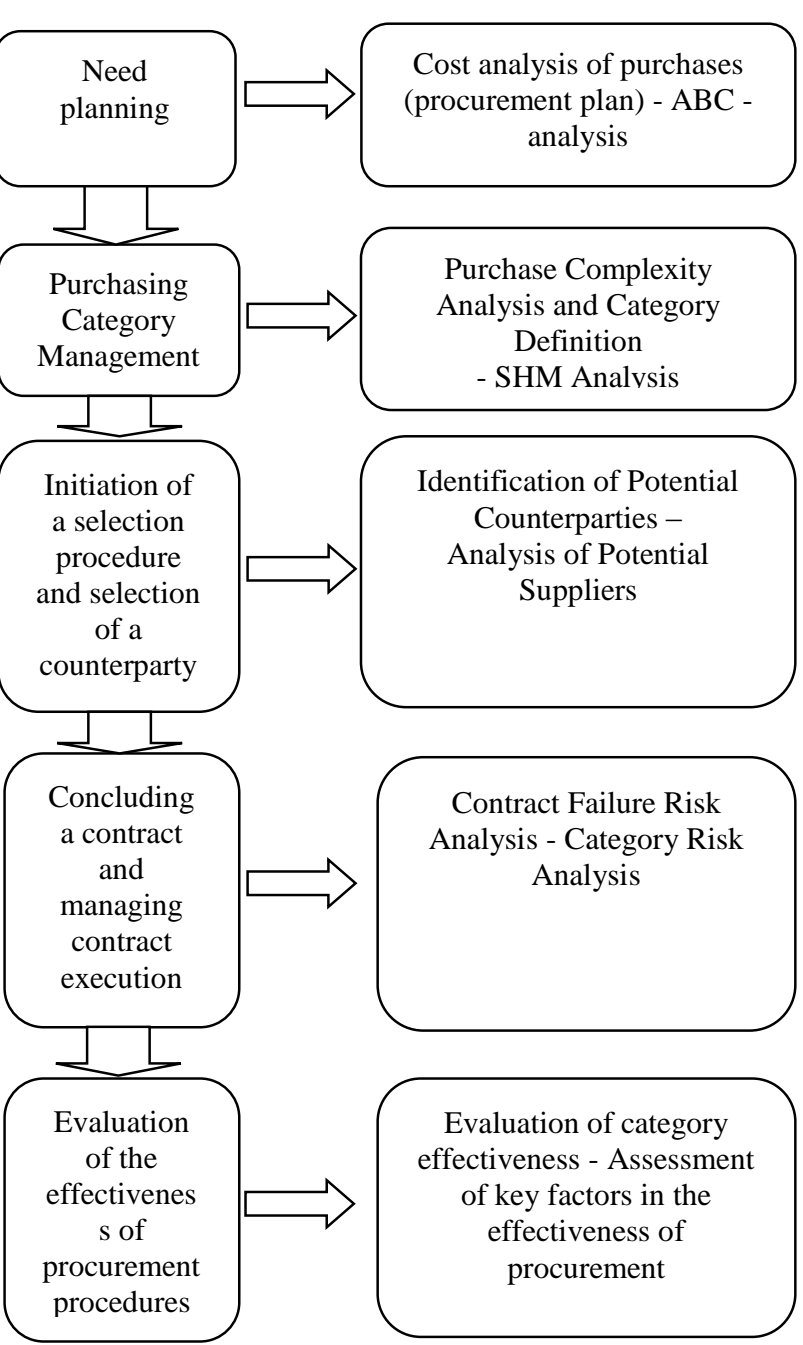

Fig. 3. The proposed category management tools in the procurement activities of the oil company

The first stages of applying the principles of category management is the division of purchases into categories. On the basis of $\mathrm{ABC}$ analysis, a valuation of purchases takes place. Often the nomenclature is categorized according to the "Pareto 80/20" principle (Figure 4).

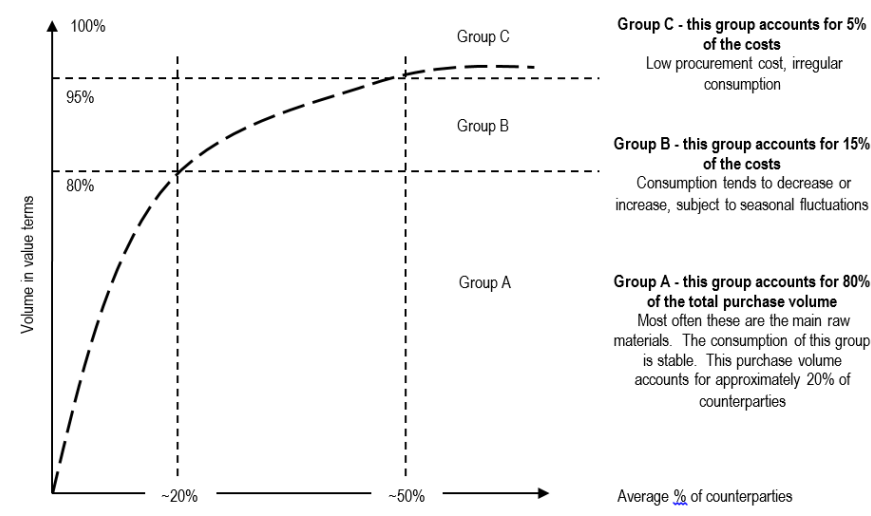

Fig. 4. Schedule of ABC - analysis of the nomenclature depending on the volume of purchases and the supplier market

Application of ABC-analysis it is advisable at the stage of formation of the procurement plan for the forthcoming period. The group purchases and get purchasing, the value of which is $80 \%$ of the total limit of funds allocated for the planning period. This group contains the most critical positions in the procurement plan.

Nomenclature MTR and PS based on the results of ABCanalysis is divided into the following groups:

1. Group a-share in value annual procurement volume of $80 \%$, consumption of this purchasing group has a strategic, stable character;

2 . The share in value annual volume $15 \%$, consumption of this purchasing group has a tendency to decrease constantly unclaimed category, the possible seasonality of demand;

3. Group - share in value annual volume of purchases around $5 \%$, consumption of this purchasing group has irregular, occasional services and ITC shared values.

After quantitative $\mathrm{ABC}$-analysis items inventory and PS annual procurement plan, requires the division of purchases by the degree of complexity, using the SHM analysis. The basis for SHM - analysis is based on the rating categories of purchases from established quantitative and qualitative criteria. As the selected criteria usually are: the type of procurement (manufacturing services and works, equipment, design and survey works, construction-Assembly works, etc.), the number of potential suppliers (competitors in supply), frequency of purchase, specialized technical requirements for purchase and other. Using the rating scale in the oil company all the purchases are categorized according to their level of complexity from the point of view of the procurement procedures and assessment of efficiency of procurement, strategic critical, tactical, and operational.

Next, on the same principle of the division of suppliers into categories based on the score-rating assessment depending on the selection criteria: assessment of reliability and reputation of the supplier, the evaluation of the experience and availability of qualified personnel, evaluation of production safety and financial reliability. This division is aimed at defining the critical characteristics of the counterparties, depends on reducing risk when purchasing a certain category. The correlation matrix of the procurement categories with the categorization of suppliers determines a preliminary list of potential suppliers for procurement.

Each of these categories depends on the specific requirements and characteristics are presented in table 1 . The ratio of the categories of suppliers with the selected procurement categories will ensure high quality provision of 
MTR and PU, as well as to reduce risks of non-fulfillment of contractual obligations.

TABLE 1. CHARACTERISTICS OF THE CATEGORIES OF PURCHASES IN THE OIL COMPANY

\begin{tabular}{|c|c|c|c|c|c|}
\hline $\begin{array}{l}\text { Purchasing } \\
\text { Category }\end{array}$ & $\begin{array}{l}\text { Vendor } \\
\text { Category }\end{array}$ & $\begin{array}{c}\text { Procurement } \\
\text { Characteristics }\end{array}$ & $\begin{array}{c}\text { Principles of the } \\
\text { procurement process }\end{array}$ & $\begin{array}{c}\text { Strategy } \\
\text { Development }\end{array}$ & $\begin{array}{c}\text { The main goals of } \\
\text { contracting }\end{array}$ \\
\hline 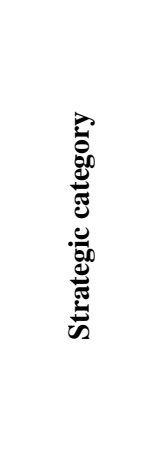 & 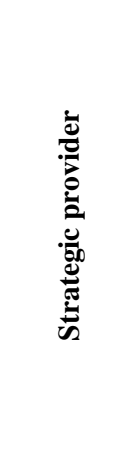 & $\begin{array}{l}\text { Strategically important } \\
\text { for manufacturing } \\
\text { activities } \\
\text { Complex specifics of } \\
\text { work / services } \\
\text { Significant costs } \\
\text { Units of qualified } \\
\text { suppliers } \\
\text { High risk purchases }\end{array}$ & $\begin{array}{l}\text { High cost of switching to } \\
\text { new suppliers: } \\
\text { Long-term partnership } \\
\text { with counterparties } \\
\text { New Supplier } \\
\text { Development } \\
\text { Building Strategic } \\
\text { Alliances }\end{array}$ & $\begin{array}{l}\text { Priority Long- } \\
\text { Term } \\
\text { Consolidated } \\
\text { Strategy }\end{array}$ & $\begin{array}{l}\text { Counterparty market } \\
\text { development: } \\
\text {-Investments in the } \\
\text { development of the project; } \\
\text {-Integration with the } \\
\text { counterparty } \\
\text { (The efforts of the } \\
\text { procurement unit are aimed } \\
\text { at supporting and } \\
\text { developing close } \\
\text { relationships with the } \\
\text { supplier, which are a } \\
\text { competitive advantage) }\end{array}$ \\
\hline : & 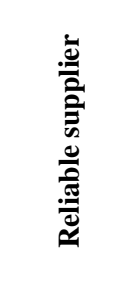 & $\begin{array}{l}\text { Technically } \\
\text { challenging needs } \\
\text { High value purchases } \\
\text { Important / large } \\
\text { volumes for production } \\
\text { Limited number of } \\
\text { qualified contractors }\end{array}$ & $\begin{array}{l}\text { Volume consolidation is } \\
\text { possible due to the high } \\
\text { cost: } \\
\text { Stable utilization of } \\
\text { contractor capacities for } \\
\text { long-term partnership }\end{array}$ & $\begin{array}{l}\text { The possibility } \\
\text { of a long-term } \\
\text { strategy to } \\
\text { achieve } \\
\text { economies of } \\
\text { scale and } \\
\text { economic } \\
\text { efficiency }\end{array}$ & $\begin{array}{l}\text { Pricing Optimization: } \\
\text {-Development of the } \\
\text { counterparty market } \\
\text { (Getting the lowest price, } \\
\text { with high competition in } \\
\text { the market due to the } \\
\text { complexity of the category) }\end{array}$ \\
\hline 莺 & 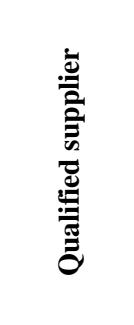 & $\begin{array}{l}\text { High cost (possibly } \\
\text { due to a limited } \\
\text { counterparty market) } \\
\text { Planned needs of non- } \\
\text { specific technical } \\
\text { production services }\end{array}$ & $\begin{array}{l}\text { Opportunity to invest in } \\
\text { counterparties to increase } \\
\text { its rating and transfer to } \\
\text { the category of strategic } \\
\text { partners }\end{array}$ & $\begin{array}{l}\text { Strategy } \\
\text { development } \\
\text { depends on the } \\
\text { level of technical } \\
\text { and } \\
\text { technological } \\
\text { complexity of } \\
\text { the procurement }\end{array}$ & $\begin{array}{l}\text { Risk optimization: } \\
\text { - Enhanced monitoring of } \\
\text { contractual obligations } \\
\text { (In view of technological } \\
\text { complexity, a high level of } \\
\text { risk categories. Control is } \\
\text { necessary throughout the } \\
\text { entire period of the } \\
\text { contractual relationship) }\end{array}$ \\
\hline 吾 & 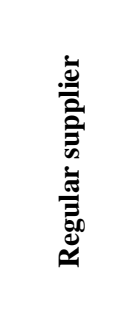 & $\begin{array}{l}\text { Extensive } \\
\text { nomenclature, simple } \\
\text { requirements } \\
\text { Low cost } \\
\text { High competition } \\
\text { among suppliers } \\
\text { Ongoing ongoing } \\
\text { needs, without narrow } \\
\text { specialized services }\end{array}$ & $\begin{array}{l}\text { Maximum automation of } \\
\text { the procurement process: } \\
\text { Standardization of } \\
\text { contractual relationships } \\
\text { to reduce the time spent } \\
\text { on the procurement } \\
\text { process }\end{array}$ & $\begin{array}{l}\text { No need for a } \\
\text { long-term } \\
\text { contracting } \\
\text { strategy }\end{array}$ & $\begin{array}{l}\text { Procedure optimization: } \\
\text { - Lower transaction costs } \\
\text { (Procurement of standard } \\
\text { contracts using open } \\
\text { competitive procedures, } \\
\text { significantly reducing the } \\
\text { contract price without loss } \\
\text { of quality) }\end{array}$ \\
\hline
\end{tabular}

To analyze the efficiency of procurement procedures by category, provides a system of assessment based on key performance indicators. When developing a methodology for assessing the effectiveness of procurement used the approved rates as recommended for procurement of goods, works and services for municipal needs of the city district of Klin [6] and proposed by specialists in the field of procurement activities of the companies $[4,5]$.
In assessing procurement performance, the following criteria: competitiveness of the procurement; economic efficiency; compliance with the administration procedures of the procurement; quality efficiency of procurement (compliance with technical specifications, industrial and environmental safety).

Method of determining performance indicators of procurement in the oil companies presented in table 2 .

TABLE II. METHODOLOGY FOR DETERMINING THE PERFORMANCE INDICATORS OF PROCUREMENT IN THE OIL COMPANY

\begin{tabular}{|l|l|l|}
\hline \multicolumn{1}{|c|}{ Performance criterion } & \multicolumn{1}{|c|}{ Indicator name } & \multicolumn{1}{c|}{ Calculation algorithm } \\
\hline Procurement competitiveness & $\begin{array}{l}\text { P1 - The share of competitive } \\
\text { procurement in total procurement }\end{array}$ & $\begin{array}{l}\text { Number of purchases made by competitive } \\
\text { methods / Total number of purchases made }\end{array}$ \\
\cline { 2 - 3 } & $\begin{array}{l}\text { P2 - The share of purchases from a } \\
\text { single supplier in the total volume of } \\
\text { purchases }\end{array}$ & $\begin{array}{l}\text { Number of purchases from a single supplier / } \\
\text { Total number of purchases made }\end{array}$ \\
\hline
\end{tabular}




\begin{tabular}{|c|c|c|}
\hline Performance criterion & Indicator name & Calculation algorithm \\
\hline & $\begin{array}{l}\text { P3 - Proportion of purchases from a } \\
\text { single supplier in the total volume of } \\
\text { purchases }\end{array}$ & $\begin{array}{l}\text { Number of purchases from a single supplier / } \\
\text { total number of purchases }\end{array}$ \\
\hline & $\begin{array}{l}\text { P3 - The average number of } \\
\text { participants in competitive } \\
\text { procurement }\end{array}$ & $\begin{array}{l}\text { The total number of declared participants in } \\
\text { competitive procedures (open tenders, } \\
\text { request for proposals, request for quotations) } \\
\text { / Number of purchases made in a competitive } \\
\text { way }\end{array}$ \\
\hline & P4 - Index of one application & $\begin{array}{l}\text { Number of purchases for participation of } \\
\text { which only one application has been filed / } \\
\text { Number of purchases made in a competitive } \\
\text { manner }\end{array}$ \\
\hline \multirow[t]{2}{*}{ Cost effectiveness } & $\begin{array}{l}\text { P5 - Savings resulting from } \\
\text { procurement }\end{array}$ & $\begin{array}{l}\text { (The difference between the initial maximum } \\
\text { price of contracts and the total value of } \\
\text { concluded contracts) / Initial maximum price } \\
\text { of contracts }\end{array}$ \\
\hline & $\begin{array}{l}\text { P6 - Procurement share with savings of } \\
\text { more than } 25 \% \text { of the initial maximum } \\
\text { contract price in the total volume of } \\
\text { competitive purchases }\end{array}$ & $\begin{array}{l}\text { Number of purchases with savings of more } \\
\text { than } 25 \% \text { of the initial maximum contract } \\
\text { price / Total number of purchases made in a } \\
\text { competitive manner }\end{array}$ \\
\hline $\begin{array}{l}\text { Procurement Administration } \\
\text { Compliance }\end{array}$ & $\begin{array}{l}\text { P7 - Coefficient of violation of the } \\
\text { requirements for the procurement } \\
\text { administration procedure (content and } \\
\text { execution of procurement } \\
\text { documentation, terms of the } \\
\text { procurement) }\end{array}$ & $\begin{array}{l}\text { Number of identified violations reflected in } \\
\text { the procurement documentation / Total } \\
\text { number of procurement protocols }\end{array}$ \\
\hline \multirow[t]{2}{*}{ Quality Procurement Efficiency } & $\begin{array}{l}\text { P8 - The indicator of the number of } \\
\text { changes in the schedule per one } \\
\text { published competitive procurement }\end{array}$ & $\begin{array}{l}\text { Number of changes in schedules / Total } \\
\text { number of purchases made in a competitive } \\
\text { manner }\end{array}$ \\
\hline & $\begin{array}{l}\text { P9 - Quality Score of Contract } \\
\text { Execution }\end{array}$ & $\begin{array}{l}\text { (Number of contracts concluded - Number of } \\
\text { terminated contracts due to default on } \\
\text { suppliers) / Number of contracts concluded }\end{array}$ \\
\hline \multirow[t]{2}{*}{ Quality Procurement Efficiency } & $\begin{array}{l}\text { P10 - The share of competitive } \\
\text { procurement not at the minimum price } \\
\text { in the total volume of purchases }\end{array}$ & $\begin{array}{l}\text { The number of competitive procurements, } \\
\text { contracts of which are not concluded at the } \\
\text { lowest price / Total number of competitive } \\
\text { procurements }\end{array}$ \\
\hline & $\begin{array}{l}\text { P11 - The proportion of applications } \\
\text { that did not participate in the selection }\end{array}$ & $\begin{array}{l}\text { (Total number of applications received - } \\
\text { Number of applications rejected) / Total } \\
\text { number of applications received }\end{array}$ \\
\hline
\end{tabular}

Next, a comprehensive assessment of the effectiveness of procurement in the company (B) is carried out, based on the determination of the aggregate indicator $\mathrm{B}$. This indicator is calculated as the sum of the values of each of the analyzed indicators using the calculation and score method:

$$
\begin{gathered}
\mathrm{B}=\mathrm{B} 1+\mathrm{B} 2+\mathrm{B} 3+\mathrm{B} 4+\mathrm{B} 5+\mathrm{B} 6+\mathrm{B} 7+ \\
+\mathrm{B} 8+\mathrm{B} 9+\mathrm{B} 11
\end{gathered}
$$

Each indicator is assigned a certain number of points in accordance with the degree of effectiveness (table 3 ).

Table 3. Proposed Performance Criteria for Strategic PROCUREMENT

\begin{tabular}{|l|l|l|l|l|}
\hline \multirow{4}{*}{ Index } & \multicolumn{4}{|c|}{ The value of the criteria for the formation of a } \\
comprehensive indicator
\end{tabular}

\begin{tabular}{|l|l|l|l|l|}
\hline \multicolumn{5}{|l|}{ Procurement competitiveness criterion } \\
\hline P1 & more 15\% & $\begin{array}{l}\text { from 7\% } \\
\text { to 15\% }\end{array}$ & $\begin{array}{l}\text { from 2\% } \\
\text { to 7\% }\end{array}$ & less 2\% \\
\hline P2 & less 60\% & $\begin{array}{l}\text { from 60\% } \\
\text { to 80\% }\end{array}$ & $\begin{array}{l}\text { from 80\% } \\
\text { to 90\% }\end{array}$ & more 90\% \\
\hline P3 & more 4 & from 3 to 4 & from 2 to 3 & less 2 \\
\hline P4 & less 5\% & $\begin{array}{l}\text { from 5\% } \\
\text { to 7\% }\end{array}$ & $\begin{array}{l}\text { from 7\% } \\
\text { to 15\% }\end{array}$ & more 15\% \\
\hline Criterion of economic efficiency \\
\hline P5 & $\begin{array}{l}\text { from 5\% to } \\
\text { from 0\% } \\
\text { to 5\% }\end{array}$ & more 20\% & - \\
\hline P6 & less 20\% & $\begin{array}{l}\text { from 20\% } \\
\text { to 25\% }\end{array}$ & $\begin{array}{l}\text { from 25\% } \\
\text { to 30\% }\end{array}$ & more 30\% \\
\hline Procurement administration compliance criteria \\
\hline P7 & - & less 5\% & $\begin{array}{l}\text { from 5\% } \\
\text { to 10\% }\end{array}$ & more 10\% \\
\hline
\end{tabular}




\begin{tabular}{|l|l|l|l|l|}
\hline \multicolumn{5}{|l|}{ Quality efficiency criterion } \\
\hline P8 & less 15\% & $\begin{array}{l}\text { from 15\% } \\
\text { to 35\% }\end{array}$ & $\begin{array}{l}\text { from 35\% } \\
\text { to 50\% }\end{array}$ & more 50\% \\
\hline P9 & more 98\% & $\begin{array}{l}\text { from 98\% } \\
\text { to 95\% }\end{array}$ & $\begin{array}{l}\text { from 95\% } \\
\text { to 90\% }\end{array}$ & less 90\% \\
\hline P10 & less 10\% & $\begin{array}{l}\text { from 10\% } \\
\text { to 20\% }\end{array}$ & $\begin{array}{l}\text { from 20\% } \\
\text { to 30\% }\end{array}$ & more 30\% \\
\hline P11 & less 5\% & $\begin{array}{l}\text { from 5\% } \\
\text { to 7\% }\end{array}$ & $\begin{array}{l}\text { from 7\% } \\
\text { to 10\% }\end{array}$ & more 10\% \\
\hline
\end{tabular}

Based on the obtained calculation values for each indicator, the final points are determined that are different for each of the procurement categories.

The boundaries of the criteria for determining the points are set in the company after a detailed retrospective analysis based on a database of business analytics for each purchase category (strategic, critical, tactical and operational).

To evaluate the effectiveness of procurement in the oil company, the authors propose the following point scale (table 4).

TABLE 4. EVALUATION OF THE EFFECTIVENESS OF PROCUREMENT

\begin{tabular}{|c|c|c|c|c|c|}
\hline \multirow[b]{2}{*}{ Criteria } & \multicolumn{4}{|c|}{$\begin{array}{l}\text { Evaluation of the } \\
\text { effectiveness of the } \\
\text { procurement of goods, } \\
\text { works, services }\end{array}$} & \multirow[b]{2}{*}{$\begin{array}{l}\text { Risks arising } \\
\text { from a low } \\
\text { criterion rating }\end{array}$} \\
\hline & 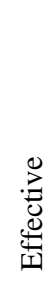 & 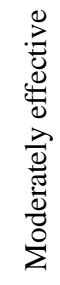 & 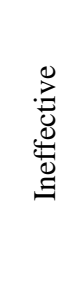 & 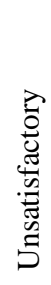 & \\
\hline & \multicolumn{4}{|c|}{ total points awarded } & \\
\hline $\begin{array}{l}\text { Procurement } \\
\text { competitiveness }\end{array}$ & $\begin{array}{l}10 \\
- \\
12 \\
\end{array}$ & $\begin{array}{l}7- \\
9\end{array}$ & $4-6$ & $\begin{array}{l}0- \\
3\end{array}$ & $\begin{array}{c}\text { Market } \\
\text { monopolization } \\
\text { risk } \\
\end{array}$ \\
\hline $\begin{array}{l}\text { Criterion of } \\
\text { economic } \\
\text { efficiency }\end{array}$ & $\begin{array}{l}5- \\
6\end{array}$ & $\begin{array}{l}3- \\
4\end{array}$ & $1-2$ & $\begin{array}{l}0- \\
1\end{array}$ & $\begin{array}{c}\text { Risk of } \\
\text { inefficient use of } \\
\text { cash }\end{array}$ \\
\hline $\begin{array}{l}\text { Administration } \\
\text { criteria }\end{array}$ & $\begin{array}{l}5- \\
6\end{array}$ & $\begin{array}{l}3- \\
4\end{array}$ & $1-2$ & $\begin{array}{l}0- \\
1\end{array}$ & $\begin{array}{l}\text { The risk of non- } \\
\text { compliance with } \\
\text { the requirements } \\
\text { of the legislation } \\
\text { and internal } \\
\text { standards of the } \\
\text { company }\end{array}$ \\
\hline $\begin{array}{l}\text { Quality } \\
\text { efficiency } \\
\text { criterion }\end{array}$ & $\begin{array}{l}8- \\
12\end{array}$ & $6-9$ & $4-6$ & $\begin{array}{l}0- \\
3\end{array}$ & $\begin{array}{l}\text { The risk of not } \\
\text { getting the } \\
\text { desired } \\
\text { production result }\end{array}$ \\
\hline $\begin{array}{l}\text { Summary } \\
\text { Evaluation of } \\
\text { Procurement } \\
\text { Efficiency } \\
\end{array}$ & $\begin{array}{l}28 \\
- \\
36\end{array}$ & $\begin{array}{c}19 \\
- \\
27\end{array}$ & $\begin{array}{c}10- \\
18\end{array}$ & $\begin{array}{c}0- \\
9\end{array}$ & \\
\hline
\end{tabular}

Based on the consolidated assessment, it is possible to evaluate the effectiveness of procurement for a particular procurement category. With this system for evaluating procurement categories, it is possible to determine the reasons for the inefficiency of the procurement procedures for the categories that scored the minimum number of points.
Thus, the proposed model of the categorization of the procurement process in the oil company will allow you to effectively manage the categories of selected procurements, forming effective contracting strategies and eliminating the onset of risk situations in the procurement activities to increase the efficiency of the oil company as a whole.

\section{RESULT}

The implementation of the proposed category management tools in the procurement activities of the oil company should be based on business analytics and the use of a database of various categories of material and technical resources and production services (BIG DATA), including a large array of quantitative and qualitative indicators, starting from the technical parameters of materials and equipment production services, ending with data on the manufacturer, supplier, assessment of the total cost of ownership of materials and equipment. The use of such business analytics will allow the oil company to correctly develop a model of the company's operating activities, taking into account the long-term partnerships with suppliers.

\section{DISCUSSION}

Most Russian and foreign scientists [7, 8, 9, 10, 11], as well as specialists from the foreign consulting firm A.T. Kearney [12] agree that in the context of global change, one of the strategic objectives of the company is its sustainable growth due to a well-built business performance strategy based on establishing long-term partnerships between customers and suppliers, as well as creating internal business efficiency -processes.

As modern practice shows, three components provide internal efficiency of business processes:

1) Human resources (people) with professional knowledge and skills in their professional field, as well as cross-functional competencies that allow working with digital technologies and making non-standard decisions based on business intelligence and a database;

2) The introduction of digital technologies that accelerate the business process, as well as reduce internal operational risks associated with the human factor;

3) The introduction of new management technologies based on the use of databases and business intelligence.

Considering procurement as an internal business process in an oil company, Russian and foreign experts give the best practices for introducing the principles of category management together with the integration of digital technologies that allow us to develop a company's procurement strategy. So, Popelas Y. proposes to use analytical tools in procurement [13], A. Yeremeyeva and Rusinov D.P. cite successful experience in improving the performance of companies based on the application of the principles of category management $[14,15]$.

\section{CONCLUSION}

Thus, the integration of modern category management tools and digital transformation in procurement will allow the oil company to meet modern business requirements, as well as ensure the operational efficiency of the company for the long term. 


\section{REFERENCES}

[1] Shmelev P. Digital transformation: the time of the first // Siberian Oil - No. 4/151. - 2018 .-- S. 14-19.

[2] Belyavtsev A. Digitalization is a fundamental trend // Siberian Oil. No. 4/151. - 2018 .-- S. 26-29.

[3] Kanenkova O. Procurement strategy is not separable from business // Procurement Director. - 2016. - No. 1. - S. 4-7.

[4] Repin S. Guidelines for strategic procurement or nine steps for organizing strategic procurement // Procurement Director. - 2016. No. 1. - S. 8-11.

[5] Klimova G.. General principles for constructing a supplier assessment model // Bulletin of the Udmurt University. Series "Economics and Law". - 2013. - No. 3. S. 34-48.

[6] Methodology for evaluating the effectiveness of the procurement of goods, works, services to meet the municipal needs of the city district of Klin, approved. By the resolution of the administration of the city district of Klin MO dated 04.19.2019 No. 720 - [Electronic resource]: http://www.consultant.ru/cons/cgi/ online.cgi? Req = doc \& base = MOB \& $n=290998 \&$ dst $=100029 \# 06217420829828668$

[7] Lingers M.R., Firon H.E. Supply and inventory management. St. Petersburg: Victoria Plus, 2002 .-- 768 p.
[8] Cousins P., Laming R., Lawson B., Squire B. Strategic Supply Chain Management. M .: Business and Service, 2010 .-- 302 p.

[9] Meyer M.V. Assessment of business performance // Marshal V. Meyer, [Trans. from English A.O. Korsunsky]. - M .: Verkhina LLC, 2004. - $272 \mathrm{p}$

[10] Kaplan R.S., Norton D.P. The Balanced Scorecard: Translating Strategy into Action. Boston: Harvard Business School Press, 1996.

[11] Popkova, E. G. and Bruno S. Sergi. Will Industry 4.0 and other innovations affect the development of Russia? Bruno S. Sergi (Ed.). A Study of the Future of the Russian Economy and Markets: Towards Sustainable Economic Development, Bingley, UK: Emerald Publishing, 2018 .-- PP.51 - 68.

[12] Making History at A.T. Kearney // Business Strategy Review. - Vol. 25. - Issue 1. - 2014. - pp. 70-72.

[13] Popelas I. Use of ABC / XYZ analysis in practice [Text]: J. Popelas. Loginfo. - 2004. - No. 1. - S.52-54.

[14] Eremeeva A.A. The use of category management tools to improve the performance of FMCG companies // Business Strategies. - 2017. - No. 12.

[15] Rusinov D.P. Category management as a new approach to managing the competitiveness of consumer goods in regional and local markets // Vestnik KSU. 2006. - No. 6. - S. 3-22. 